\title{
THE FUNCTIONAL MORPHOLOGY OF THE ROCK-BORING LAMELLIBRANCH PETRICOLA PHOLADIFORMIS LAMARCK
}

\author{
By R. D. Purchon \\ Raffles Professor of Zoology, University of Malaya, Singapore
}

(Text-figs. I-I6)

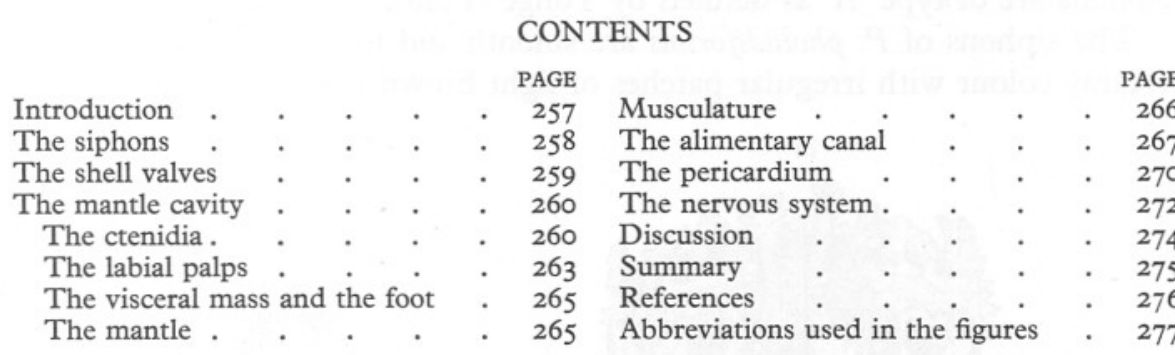

\section{INTRODUCTION}

While the writer was engaged in a study of the British species of Pholadidae, an opportunity arose also to study Petricola pholadiformis Lamarck (see Winckworth, I932), a rock-boring lamellibranch belonging to the Petricolidae. This species is of special interest as it is considered to exhibit convergent evolution with respect to Barnea candida, one of the British species of Pholadidae.

The specimens were obtained from Burnham-on-Crouch, Essex, where they were collected near low-water mark by Mr G. D. Waugh, to whom the writer wishes to express his gratitude. Living and preserved specimens of Petricola pholadiformis were studied in 1950 at the Department of Zoology and Comparative Anatomy, University College of South Wales and Monmouthshire, Cardiff.

The most important paper on Petricola is that of Lamy (1923), who reviewed the genus, describing $P$. pholadiformis Lamarck, and giving its synonyms. He described the distribution of this species on the Atlantic Coast of North America, and on the West Coast of Africa. He recorded its arrival in European waters, where it was observed on the coast of Kent in I893. The genus is briefly mentioned by Sikes (I910), Calman (I919), Schlesch (1932), Calman \& Crawford (1936), and Coe (1943). Other direct references to Petricola will be referred to in the appropriate places; wider references to literature are made in a paper on the British Pholadidae (Purchon, I955). 


\section{THE SiPHONS}

The basal half of the siphonal process is formed by fusion of the inhalant and exhalant siphons (Fig. 4). The siphons are separate for their distal halves, the inhalant being slightly longer than the exhalant siphon (Morse, I9I9). When fully extended, the siphons are a little longer than the shell valves. The siphons are formed solely from the inner lobes of the mantle margin, and are unprotected by periostracum. The middle and outer lobes of the mantle form a crescentic ridge passing round the base of the siphonal process, parallel to the edge of the shell (Figs. 4, 9, Olm), and giving rise to a thin transparent sheet of periostracum which passes to the margin of the shell valves. Thus the siphons are of type 'A' as defined by Yonge (1948).

The siphons of $P$. pholadiformis are smooth and the flesh is of an opaque creamy colour with irregular patches of light brown pigment distally.

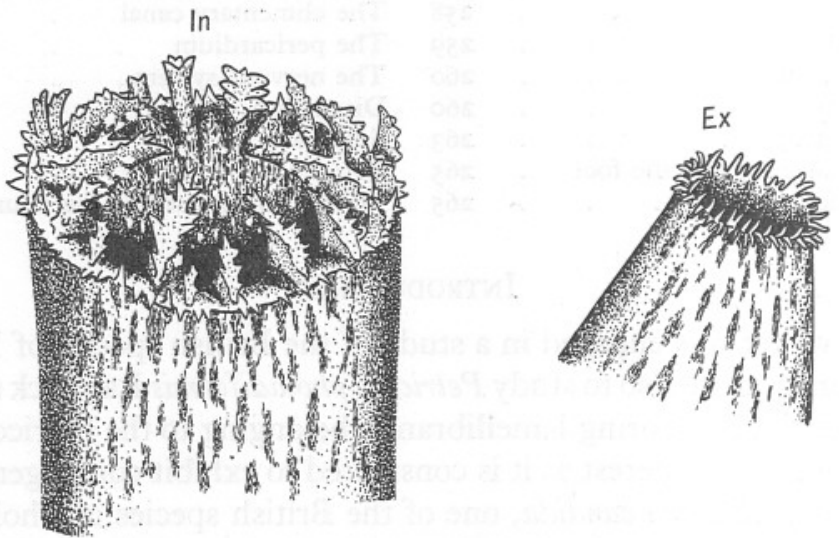

Fig. I. P. pholadiformis, free-hand drawing of the tips of the siphons. Shell length $\mathrm{r} \cdot 5$ in. $\times 7 \cdot 5$.

The inhalant aperture is surrounded by a series of irregularly pinnate tentacles of various sizes (Fig. I, In). These may be roughly classified as primary, secondary, tertiary and even quaternary according to size, the quaternary tentacles lying closest to the outer margin and being smallest and simplest. There was much variation from specimen to specimen in the sample studied, but there tended to be about six primary tentacles which normally projected across the inhalant aperture. There were about as many smaller secondary tentacles and, external to these, a larger number of still smaller and simpler tertiary tentacles. At the periphery, external to the twenty-four or more tertiary tentacles, there was a ring of about forty-eight small marginal papillae.

The primary, secondary and tertiary pinnate tentacles are very similar in form and pigmentation to the pinnate tentacles of Zirphaea crispata (see 
Purchon, 1955). In addition, however, in Petricola pholadiformis there are occasional opaque white patches on the sides of the tentacles and on the inner surface of the inhalant siphon.

Unlike the inhalant siphon, the exhalant siphon tapers slightly towards its extremity which is similarly ornamented by irregular brown patches (Fig. I, Ex). The exhalant aperture is surrounded by a variable number of small conical tentacles which tend to be arranged in two circles, the inner consisting of about twenty-four tentacles, some of which may be united at their bases in pairs. The outer ring consists of a larger number of smaller tentacles.

When observed in aquaria, the siphons were seldom extended far, the base of the siphonal process generally being partly introverted between the posterior ends of the shell valves. They undergo slight contractions and expansions which are possibly more pronounced under natural conditions.

\section{The Shell VAlves}

The shell of $P$. pholadiformis superficially resembles that of Barnea candida (see Purchon, I955) and the two species may be found burrowing side by side. Petricola may be readily distinguished, however, by the absence of accessory shell plates and by the presence of a conspicuous external ligament. Internally the differences between Petricola and Barnea are equally pronounced.

The hinge teeth are well developed (Figs. 2, 3, Ht) and these, together with the elongated external ligament (Fig. 2, $L$ ) will undoubtedly prevent any rocking of the shell valves about a vertical axis, as has evolved in the Adesmacea. The adductor scars are in the typical positions ventral to the hinge line, the anterior adductor scar being only a little less in area than that of the posterior adductor muscle.

In the shell drawn, the pallial sinus penetrated to $60 \%$ of the total shell length, a value of the same order as has been found in the Pholadidae (Purchon, I955); Petricola pholadiformis is certainly well adapted for burrowing, if not for boring. There is no 'accessory ventral adductor' in P. pholadiformis (as is present in the Adesmacea), but there is an 'accessory dorsal adductor muscle', dorsal to the rectum (Fig. I4, $A p a$ ).

The habit of the specimens here studied has been described by Mr G. D. Waugh (personal communication) as boring in lumps of chalk which lie on the mud at low-water mark. In some cases specimens had bored through the chalk and their anterior ends had entered the underlying mud. Petricola is apparently only able to bore into very soft rocks, perforation being presumably by opening and closing of the shell valves on the hinge line as an axis. This view was held by Otter (I937) for P. lapicida, the burrow of which he described as oval in section. 


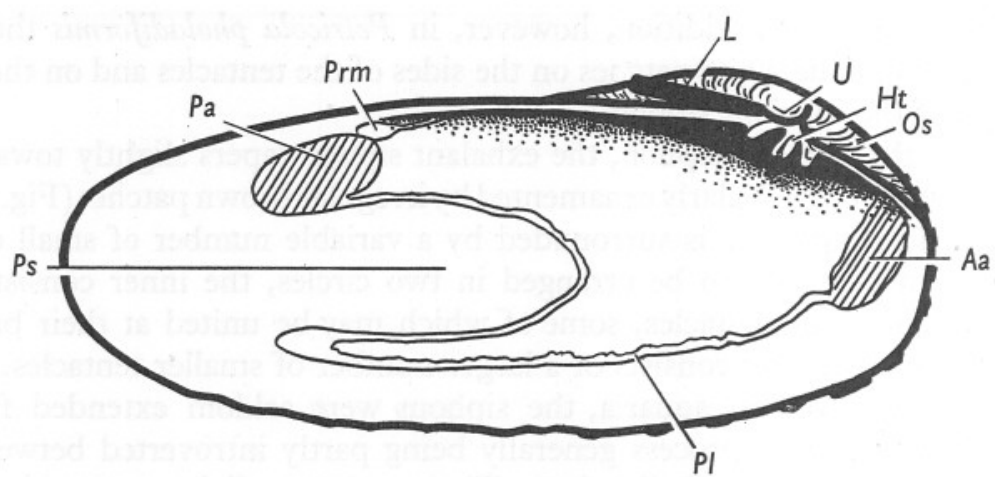

Fig. 2. P. pholadiformis, interior of the left shell valve. Shell length $2 \cdot 3$ in. $\times I \cdot 5$. For lettering see pp. 277-8.

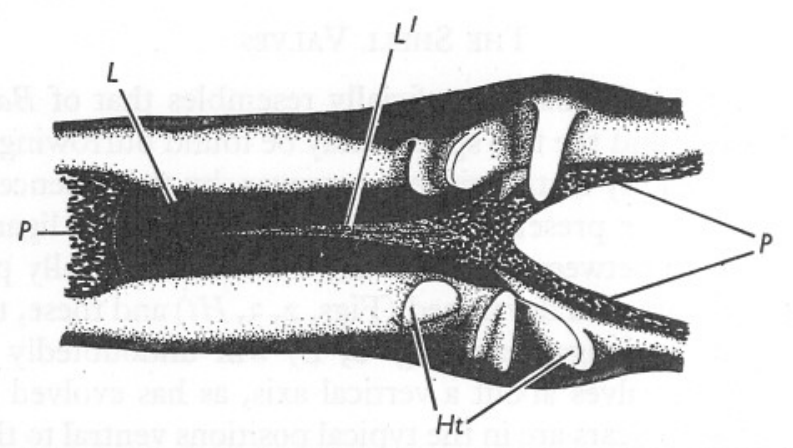

Fig. 3. P. pholadiformis. Ventral view of a portion of the hinge line of two shell valves, the valves being widely parted. The anterior end is to the right. Shell length $\mathrm{I} \cdot 7$ in. $\times 5 \cdot 3$. For lettering see pp. 277-8.

\section{The Mantle Cavity}

The disposition of the organs in the mantle cavity is shown in Fig. 4. Detailed description is not necessary. The most important features of the various organs will be outlined in the following sections.

The pedal gape is long, and amounts to about half of the length of the shell (Fig. 4). There is an annular backwardly directed valve in the bases of both the inhalant and the exhalant siphons (Fig. 4, V). According to Haas (I929-40) such valves occur in many families. Similar valves are present in Pholadidea loscombiana (see Purchon, 1955).

\section{The Ctenida}

The outer demibranch (Fig. 4, Alod) does not reach as far forwards as the inner demibranch, much of which is therefore exposed to the action of the sorting areas of the outer labial palp (Rolp). Particles carried forwards either 


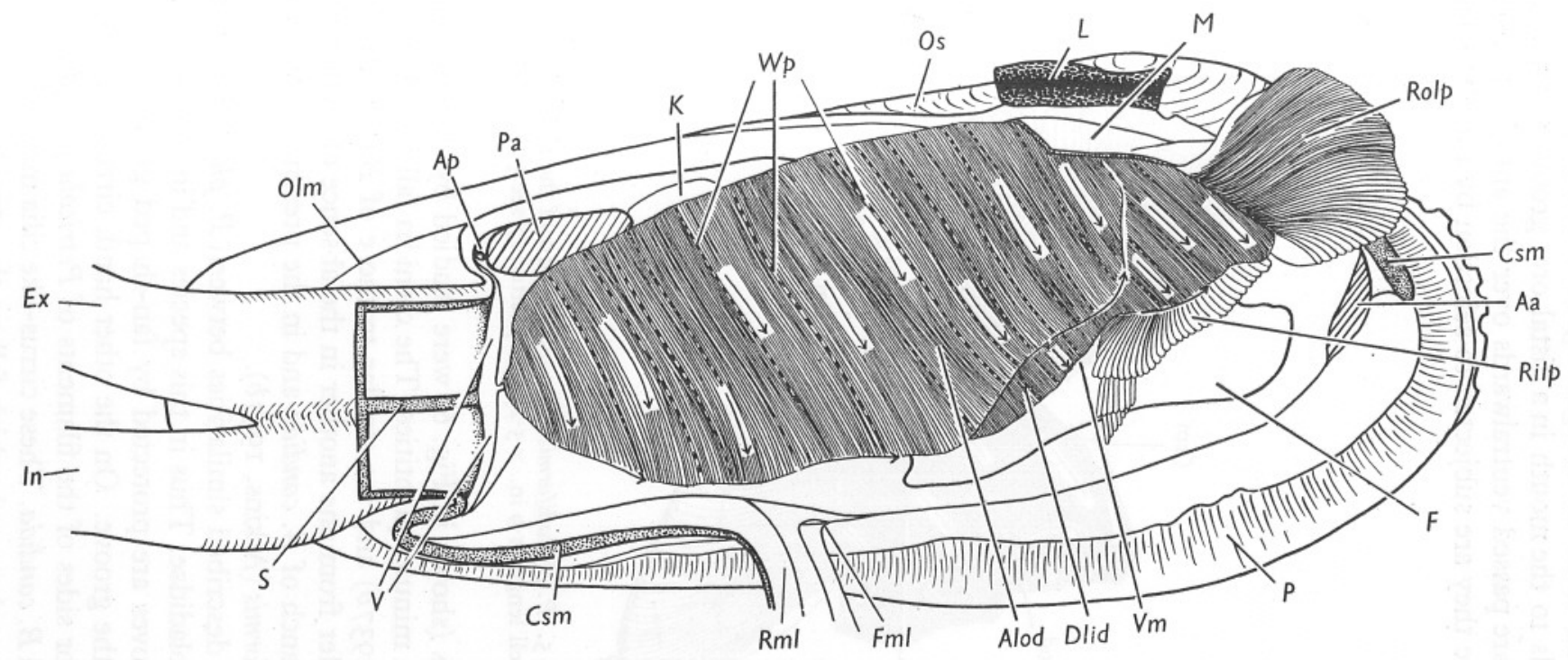

Fig. 4. P. pholadiformis. Organs in the mantle cavity. The right shell valve and most of the right mantle lobe have been removed. Shell length $\mathrm{I} \cdot 9$ in. $\times 3$. For lettering see pp. $277-8$. 
in the ctenidial axis or in the marginal groove of the outer demibranch do not travel forwards to the mouth in a distal oral groove anterior to the inner demibranch, but are passed ventralwards over the anterior part of the inner demibranch where they are subjected to selection by the outer labial palp.

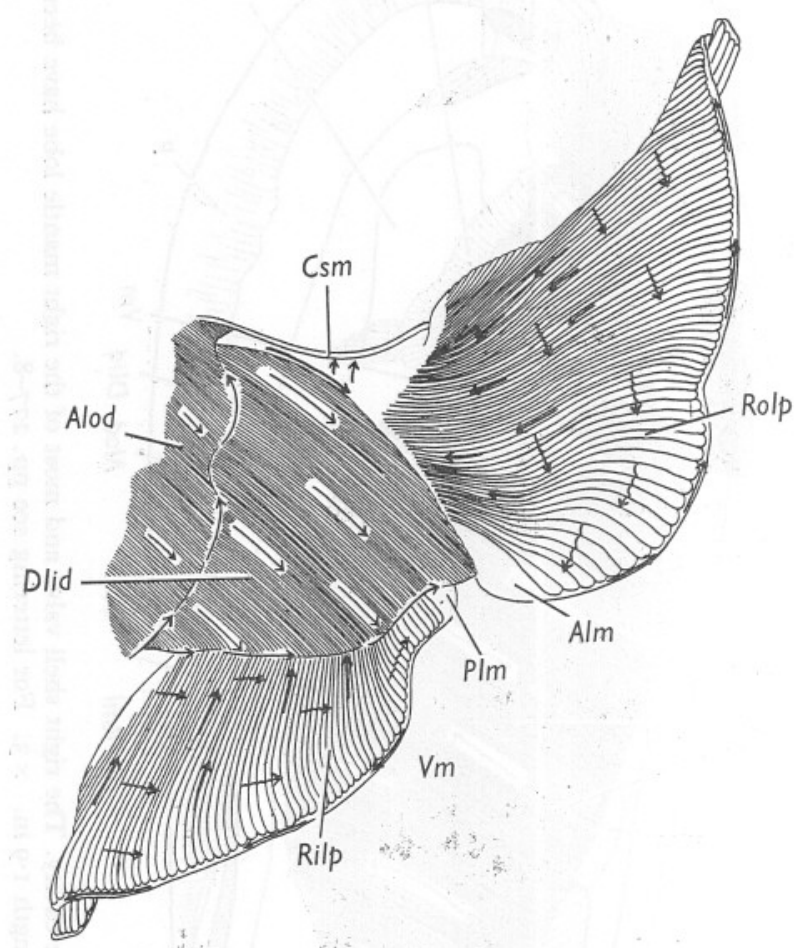

Fig. 5. P. pholadiformis. The labial palps of the right side. Shell length $I \cdot 9$ in. $\times 5 \cdot 25$. For lettering see pp. $277-8$.

Ciliary currents (shown in Fig. 6) were studied by the application of carborundum $F_{3}$ in minute quantities. The ctenidia fall into Atkins's Category $\mathrm{C}(\mathrm{I} c)$ (Atkins, I937b) and are similar to those of Barnea candida (Atkins, I937a). They differ from one another in the absence of a marginal groove in the outer demibranch of $B$. candida and in the presence of weak plication in Petricola pholadiformis (Atkins, I937 b).

Atkins (I937a) described similarities between $P$. pholadiformis and various species of the Pholadidae. Thus in this species and in Pholadidea loscombiana the marginal grooves are protected by fan-shaped groups of guarding cilia which arch over the groove. On the other hand, cirrus-like cilia are present along the posterior sides of the filaments of Petricola pholadiformis and both Barnea parva and B. candida. These cirrus-like cilia may aid in the removal of large particles of sand or rock which fall on the ctenidia. 
There are a number of points in which Petricola pholadiformis resembles Barnea candida, the most remarkable of which is the presence of opposing ciliary currents on the filaments of the descending lamella of the outer demibranch (Fig. 6). The two species live side by side occasionally, e.g. at Burnhamon-Crouch, and the similarity between their ctenidia may reasonably be regarded as parallel adaptation to similar environmental conditions. This has been discussed by Purchon (1955).

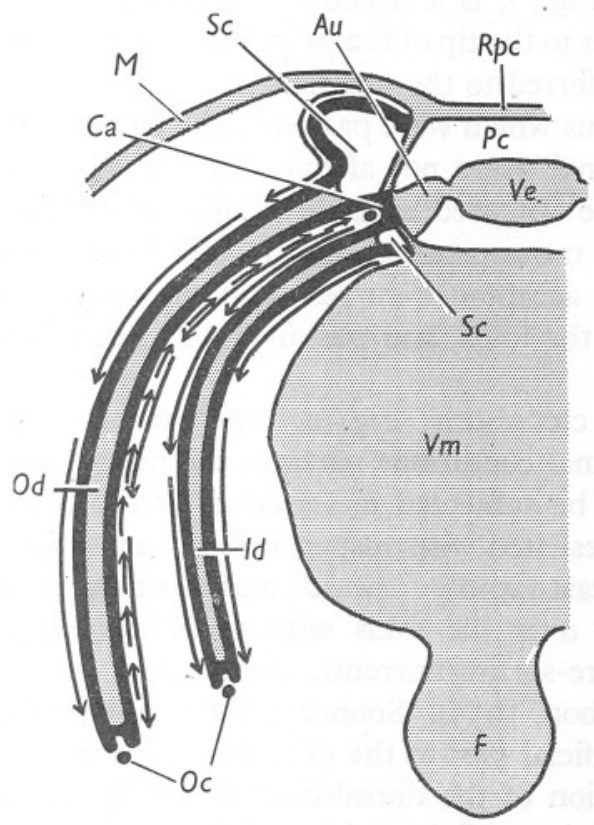

Fig. 6.

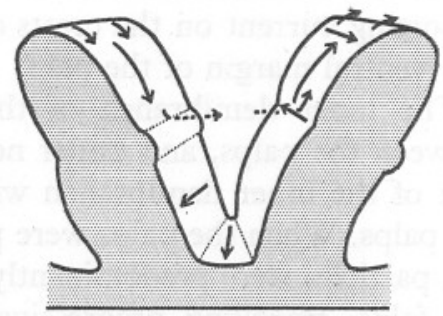

Fig. 7 .

Fig. 6. P. pholadiformis, a thick hand-cut transverse section through the body in the region of the pericardium. $\times$ Io.

Fig. 7. P. pholadiformis. Diagrammatic representation of the ciliary pattern on the folds of the labial palps. Anterior side to the right.

For lettering see pp. 277-8.

\section{The Labial Palps}

The labial palps are extremely active, and are continually coiling and uncoiling as is indicated in Fig. 4, Rilp. The ridges on the opposed surfaces of the palps may be thrown violently into zigzags on the slightest mechanical stimulation of the palps.

The detailed ciliary pattern on the folds of the palps is shown in Fig. 7 . The following ciliary currents may be recognized:

(I) A rejection current on the floor and sides of the groove between adjacent folds on the palp. Particles are driven to the free ventral border of the palp. 
(2) An acceptance current operating on the superficial slopes and on the crests of the folds, carrying particles forwards from fold to fold, towards the mouth.

(3) A ventralward re-sorting current on the crest of each fold, carrying particles towards the ventral border of the palp.

(4) A dorsalward re-sorting current carrying particles in the superficial part of each groove, towards the base of the palp and the lateral oral groove.

In addition, and not shown in Fig. 7, is a rejection tract which conveys material from the grooves backwards to the tip of the palp along its free ventral border. This material is then transferred to the mantle.

Skeins of particles bound in mucus which were passed to the palp from the anterior end of the inner demibranch were not affected by the dorsalward re-sorting currents, since these were obscured by the overlapping of adjacent folds. Such material was rapidly transported anteriorly and ventralwards under the combined action of the acceptance current and the ventralward re-sorting current on the crests of the folds, and was always rejected via the free ventral margin of the palp.

The inner demibranch of the ctenidium (Fig. 4, Dlid) passes deeply between the palps, and under normal conditions particles moving over that part of the inner demibranch will be subjected to selection by the folds of the palps. When the palps were presented with suspensions of carborundum $F_{3}$, particles were predominantly cast rapidly forwards and downwards over the folds, travelling progressively over the folds without being deflected dorsalwards or ventralwards by the re-sorting currents. Such action was never to be seen in the Pholadidae (Purchon, 1955). Sooner or later, however, the particles were trapped in the superficial part of the grooves, and were transported dorsalwards due to the action of the dorsalward re-sorting current. These particles accumulated at the base of the palp, and together with any particles brought thither by the ctenidial axis, passed into the lateral oral groove and thence rapidly to the mouth where they were ingested. Very little entered the deepest part of the grooves to be rejected via the free ventral border of the palp.

In the specimens studied, there was no suggestion of intermittent feeding, as was noted in the Pholadidae (Purchon, 1955), and it was concluded that the palps were far less selective than those of the Pholadidae.

It appears that the palps accept fine and medium-sized particles and convey them to the mouth, but reject mucus-bound material such as is likely to be presented to the palps when the water contains much suspended material.

On the outer smooth surfaces of the palps the cilia beat dorsalwards, and particles were carried over the postero-dorsal free margin of the palps and on to the ridged inner surfaces. 


\section{The Visceral Mass and the Foot}

- The foot is plough-shaped, and lies along the whole ventral border of the visceral mass (Fig. 4, F). A broad, apparently unciliated area on the side of the visceral mass (Fig. 8, Ia) corresponds in shape and position with that of the inner labial palp, while no ciliary activity could be detected on the sides of the foot. Over the postero-dorsal half of the visceral mass, the ciliary currents carried particles ventralwards, and into posteriorward rejection tracts which carried all material on the sides of the visceral mass to its posterior end. Particles falling on the sides of the visceral mass will presumably be cleared by the labial palps.

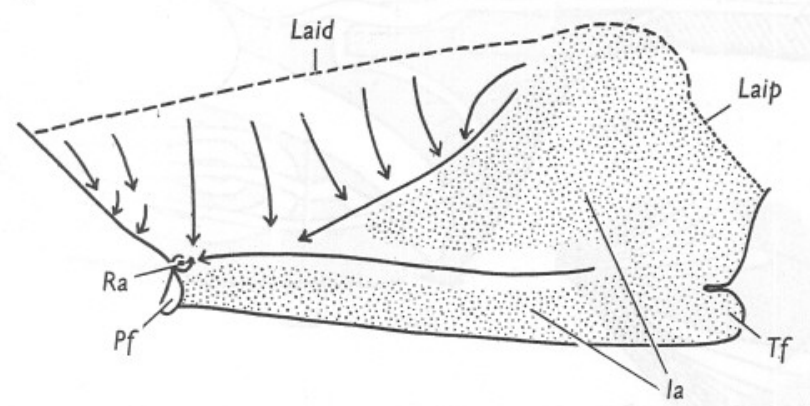

Fig. 8. P. pholadiformis. Ciliary currents on the right side of the visceral mass. Shell length $2 \cdot 3$ in. $\times 2 \cdot 7$. For lettering see pp. 277-8.

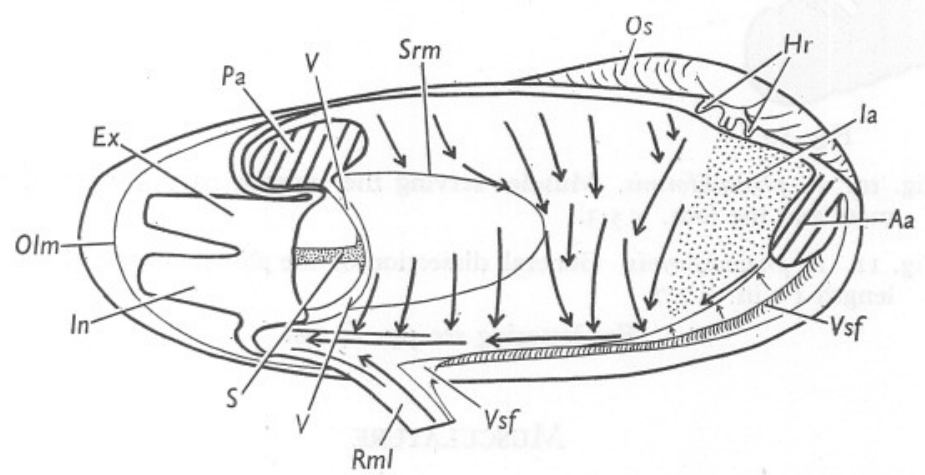

Fig. 9. P. pholadiformis. Ciliary currents on the inner surface of the left lobe of the mantle. Shell length $I \cdot 9$ in. $\times I \cdot 35$. For lettering see pp. $277-8$.

\section{The Mantle}

In order to study the ciliation of the inner surface of the mantle, the visceral mass and ctenidia were removed and the preparation was left for some hours to allow the muscles to relax and the siphonal process to expand somewhat. There is a broad triangular area anteriorly, which is apparently unciliated and which corresponds in shape and position with that of the outer labial palp (Fig. 9, Ia). 
Over the greater part of the mantle the ciliary action is ventralwards, carrying particles towards the margin of the mantle. There is a powerful rejection tract near the mantle margin. This arises near the mouth, passes backwards on the side of the pedal gape, and joins with its partner from the other side of the body posterior to the pedal gape. Under experimental conditions, waste material collects in a small pocket at the base of the siphonal process; it is not certain whether this would or would not occur under natural conditions.

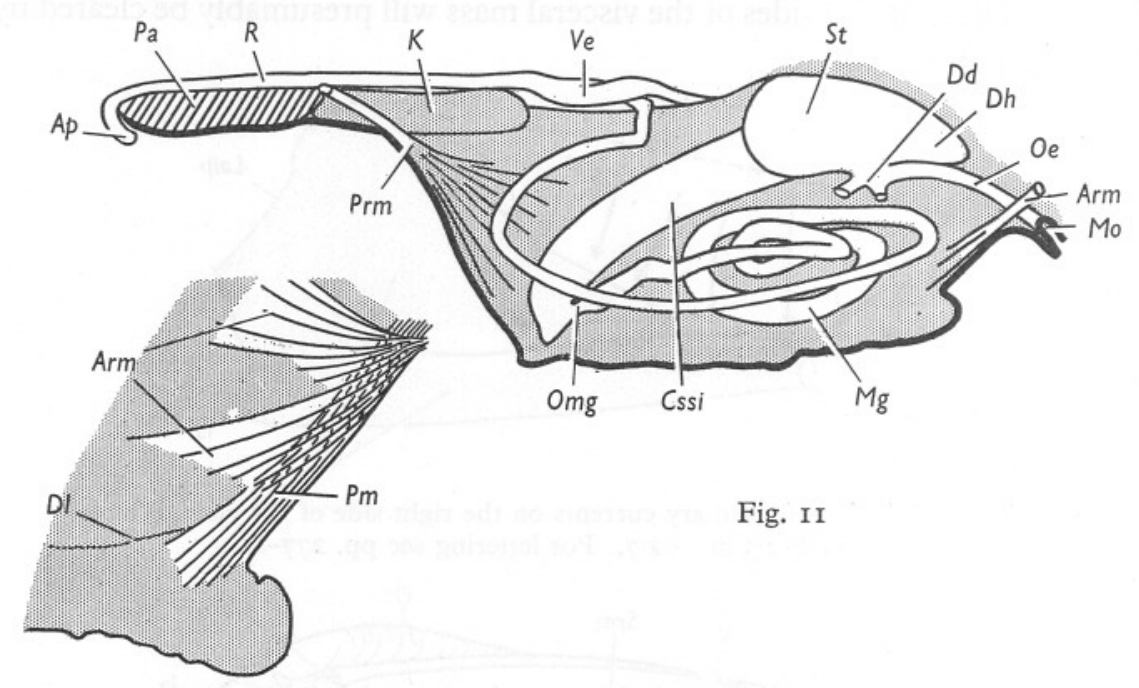

Fig. I0

Fig. Io. P. pholadiformis. Muscles serving the anterior part of the visceral mass and the foot. $\times 5.3$.

Fig. II. P. pholadiformis. General dissection of the alimentary canal. Shell length $\mathrm{I} \cdot 9$ in. $\times 2 \cdot 7$.

For lettering see pp. $277-8$.

\section{MUSCULATURE}

Unlike the Pholadidae (Purchon, 1955), the anterior adductor scar of Petricola pholadiformis is smaller in area than that of the posterior adductor, being $70 \%$ of the area in the shell drawn (Fig. 2). Another difference is the position of the anterior adductor scar ventral to the hinge line. There is an 'Accessory Posterior Adductor Muscle', which lies anterior to the posterior adductor and dorsal to the rectum (Fig. I4, $A p a$ ).

The anterior retractor muscle of the visceral mass. This arises as a flattened sheet a little posterior to the anterior adductor (Fig. Io, $\mathrm{Arm}$ ). Its fibres spread out immediately below the epidermis on the antero-dorsal surface of the visceral mass. 
The posterior retractor muscle of the visceral mass. This arises anterior to the posterior adductor (Figs. 2, I I, Prm), and it is more powerfully developed than that of the Pholadidae. At the postero-dorsal angle of the visceral mass the left and right muscles meet and a proportion of fibres cross over from side to side.

Pedal retractor muscle. This arises immediately behind the anterior adductor, and internal to the base of the anterior retractor of the visceral mass; it is a stout bundle, elliptical in section (Fig. Io, $\mathrm{Pm}$ ). The muscle passes downwards along the anterior face of the visceral mass and as it approaches the muscular tissues of the foot it spreads out posteriorly, and there is a mingling of fibres from left and right sides as the two muscles enter the foot.

Transverse muscle fibres in the visceral mass. Here and there, transverse muscle fibres arise in the epithelium of the visceral mass and pass inwards either to the walls of the alimentary canal or transversely across the visceral mass to the opposite side. No such muscle bundles were found in the Pholadidae, though a few muscle fibres were found in Zirphaea crispata inserted into the sides of the oesophagus and the anterior face of the stomach (Purchon, 1955).

\section{The Alimentary Canal}

A general dissection of the alimentary canal was carried out on specimens that had been relaxed with menthol and magnesium sulphate, and had then been preserved in alcohol (Fig. II). The oesophagus enters the ventral wall of the stomach and its base is overlapped by an outgrowth of the stomach, the dorsal hood (Fig. I I, Dh). The apertures from the stomach into the digestive diverticula $(D d)$ lie on the ventral surface of the stomach. The combined style sac and mid-gut, the cavities of which are incompletely separated by a typhlosole, arise on the postero-ventral surface of the stomach and pass backwards and downwards towards the heel of the foot. The mid-gut passes from the distal end of this wider tube, coils on the ventral side of the stomach and then passes backwards and upwards to the pericardium. The hind-gut penetrates the ventricle, passes ventral to the accessory posterior adductor (Fig. I4, $A p a$ ), as noted in the previous section, and terminates in an anal papilla in the typical manner.

The internal structure of the stomach was studied on living specimens. The epithelium covering the visceral mass was removed and the stomach exposed by scraping away gonadial tissues, and by loosening the mass of digestive diverticula. A mid-dorsal incision was made in the stomach wall, and the right side of the stomach was drawn downwards. The dorsal hood was opened, giving a view comparable to that shown in Fig. I2, in which the oesophageal aperture is hidden from view by the anterior part of the gastric shield (Gs).

The dorsal hood arches forwards above the oesophagus and opens into the stomach anteriorly on its right side $(O d h)$. Its ventral wall is covered with a finely ridged sorting area (Fig. I2, $\mathrm{Sa}$ ). Here cilia beat transversely over the 
crests of the folds towards the apex of the hood on the left-hand side $\left(D h^{\prime}\right)$, whereas in the grooves the cilia beat backwards and finally reject material via the mouth of the hood $(\mathrm{Odh})$ into the intestinal groove (Gi).

The roof of the dorsal hood is smooth, and ciliary currents on it pass material backwards, over the right side of the stomach and into the mid-gut. The posterior wall of the dorsal hood bears a minor sorting area $\left(S a^{\prime}\right)$ which passes out of the mouth of the dorsal hood, and across the anterior face of the

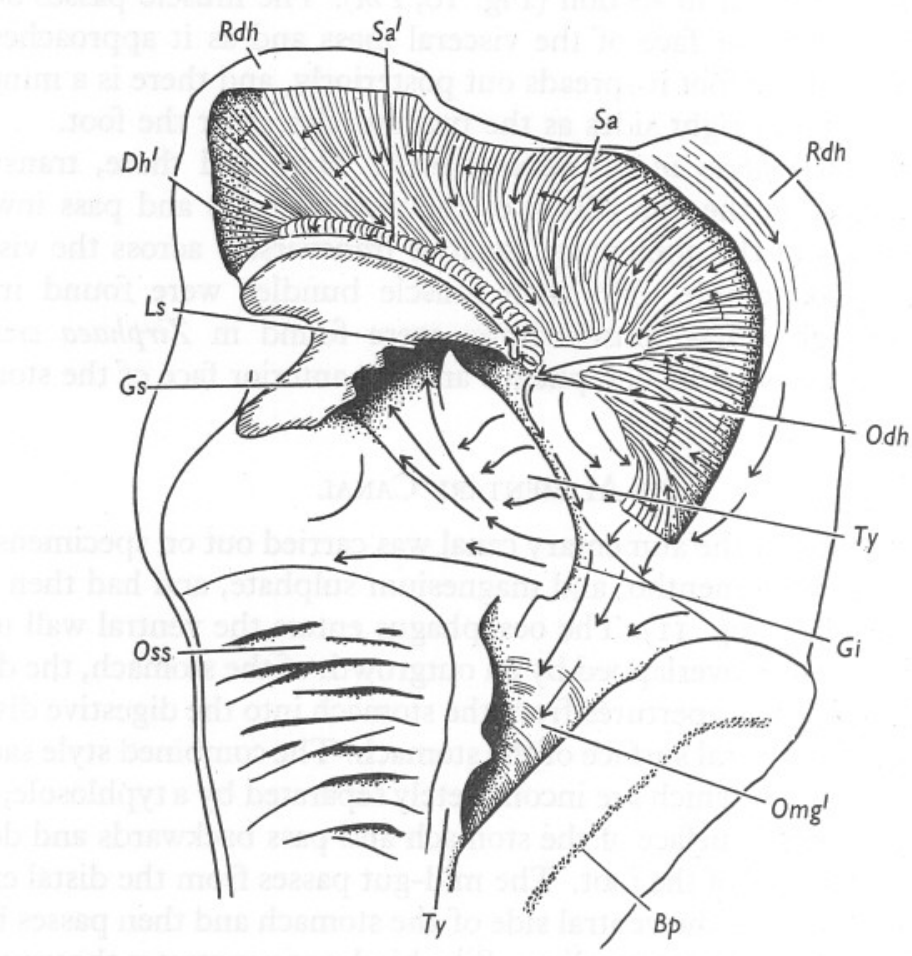

Fig. I2. P. pholadiformis. Interior of the stomach. The stomach has been opened by a middorsal incision through the roof of the stomach and style sac, and through the roof of the dorsal hood. Shell length $r \cdot 9$ in. $\times 9$. For lettering see pp. 277-8.

stomach below the oesophageal aperture (Fig. I3, $S a^{\prime}, S a^{\prime \prime}$ ). It probably serves to carry particles from the anterior face of the stomach into the dorsal hood.

The left pouch of Petricola pholadiformis can be exposed by cutting transversely to the left through the gastric shield (Fig. I2, Gs). The sides and floor of the left pouch can now be seen, as also the aperture of the oesophagus into the stomach (Fig. I3). Reference to this figure shows that there is a slender belt of transverse ridges on the roof of the left pouch, there is an extensive sorting area $\left(S a^{\prime \prime \prime}\right)$ on the floor of the left pouch, and there are also three ducts 
leading from the left pouch into the digestive diverticula $(D d d)$. It is important to note that the ciliary currents detected in the left pouch do not assist particles to pass into the ducts of the digestive diverticula-on the contrary, the reverse is true.

The major typhlosole (Fig. I3, $\left.T y^{\prime}\right)$ arises in the left caecum $(D d l)$, crosses the anterior face of the stomach ventral to the oesophageal aperture and enters the mouth of the right caecum $(D d r)$. It emerges from the right caecum and travels posteriorly along the right side of the floor of the stomach $(T y)$, accompanied all the way by the intestinal groove $(G i)$ and passes into the mid-gut (Fig. I2, $\mathrm{Omg}^{\prime}$ ).

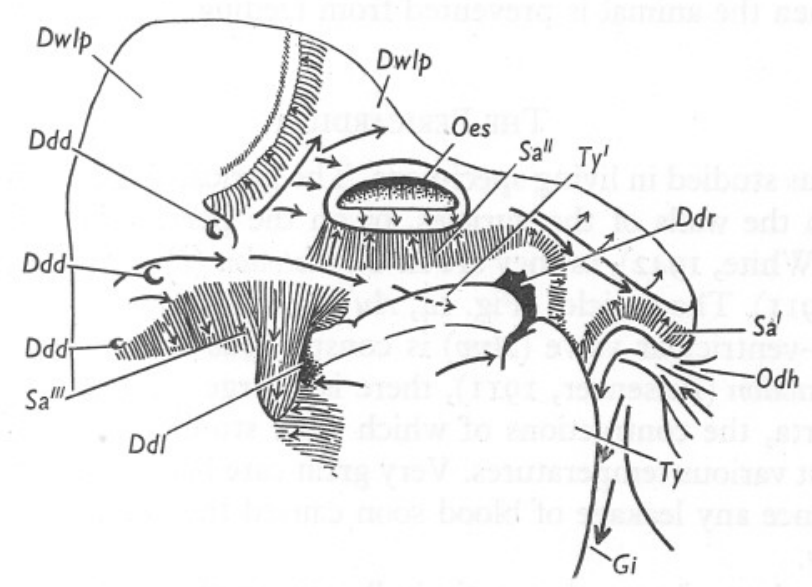

Fig. 13. P. pholadiformis. A dorsal view of the anterior part of the stomach, the roof of the left pouch having been cut and turned forwards. $\times 8$. For lettering see pp. $277-8$.

The sorting areas described above, in the left pouch, on the anterior face of the stomach, and in the dorsal hood, appear to be expressly designed to hinder the passage of particles from the stomach into the ducts of the digestive diverticula, and to reject any particles captured into the intestinal groove. This applies as much to the ducts of the digestive diverticula which open via the left caecum and the right caecum, as to the ducts that open into the stomach via the left pouch.

Within the mouths of the left and right caeca, the cilia beat inwards, and will carry particles into the ducts of the digestive diverticula. There is no definite ciliary route carrying particles to the left caecum, but particles rejected from the left caecum via the intestinal groove are carried into the right caecum. The intestinal groove finally removes particles rejected by the right caecum, and passes them into the mid-gut.

It appears probable therefore that, as previously noted for the Pholadidae, food material cannot be passed from the stomach into the digestive diverticula solely by ciliary activity. Probably muscular activity is also involved. Changes 
in the relative volumes of the stomach and the various parts of the digestive diverticula, their ducts and the left and right caeca, could cause stomach contents to be sucked or injected into the digestive diverticula.

Such volumetric changes might be caused by action of the adductor muscles, and by movements of the foot by the pedal muscles. The walls of the stomach may also contribute to movement of the stomach contents. Considerable muscular activity was noted in the wall of the living stomach of $P$. pholadiformis.

It has not been possible to study the action of the crystalline style in the stomach of $P$. pholadiformis. Where the style sac is not completely separated from the lumen of the mid-gut, as in this species, the crystalline style readily dissolves when the animal is prevented from feeding (Yonge, I926).

\section{The Pericardium}

The heart was studied in living specimens. The pericardial glands, which may either lie on the walls of the auricles, or on the pericardial walls, are here pericardial (White, I942), as they are in Choristodon (Petricola) lapicidum (see Pelseneer, I9I I). The auricles (Fig. I4, $A u$ ) are triangular with thin walls and the auriculo-ventricular valve $(A v v)$ is conspicuous by its opacity and size. As in Choristodon (Pelseneer, I9II), there is a large aortic bulb $(A b)$ on the posterior aorta, the contractions of which were studied on freshly captured specimens, at various temperatures. Very great care had to be exercised in the dissection since any leakage of blood soon caused the aortic bulb to collapse permanently.

In dissected specimens the aortic bulb remained inactive as long as the siphons remained withdrawn, but a short time after the work of dissection was completed the siphons were usually protruded slightly and the aortic bulb then became active. After some time, due probably to the gradual loss of blood, the activity of the aortic bulb decreased, and it diminished in size. In Fig. I4 the ventricle is drawn in a contracted state, and the aortic bulb in a moderately expanded state.

By subjecting animals to variations in water temperature, from about $6^{\circ} \mathrm{C}$ to about $30^{\circ} \mathrm{C}$, the rate of beat of the ventricle was found to increase with increasing temperature, but the rate of beat of the aortic bulb was unrelated to temperature. Each beat of the aortic bulb was related to movements of the siphons, which were not related to change in temperature.

The aortic bulb evidently acts both as a safety valve, protecting the ventricle from the effects of a sudden flow of blood from the siphons along the posterior aorta, and also as a reservoir which can quickly supply blood for the subsequent expansion of the siphons. Siphonal contraction and expansion involve considerable movements of blood, and the value of an aortic bulb to a bivalve with very active siphons is obvious.

Specimens of Scrobicularia plana were dissected for comparison. This 
species, which feeds on bottom deposits by means of its inhalant siphon, has very long, separate, and active siphons (Yonge, 1949). As was expected, a large and active aortic bulb was found on the posterior aorta in this species. An animal such as Petricola pholadiformis, living in a burrow, and possessing siphons that are united at their bases, may not have to execute very extensive contractions of the siphons in order to bring them within the protection of the burrow. The retention of an active aortic bulb, therefore, may perhaps be taken to indicate that this form has recently taken to a rock-boring mode of life.

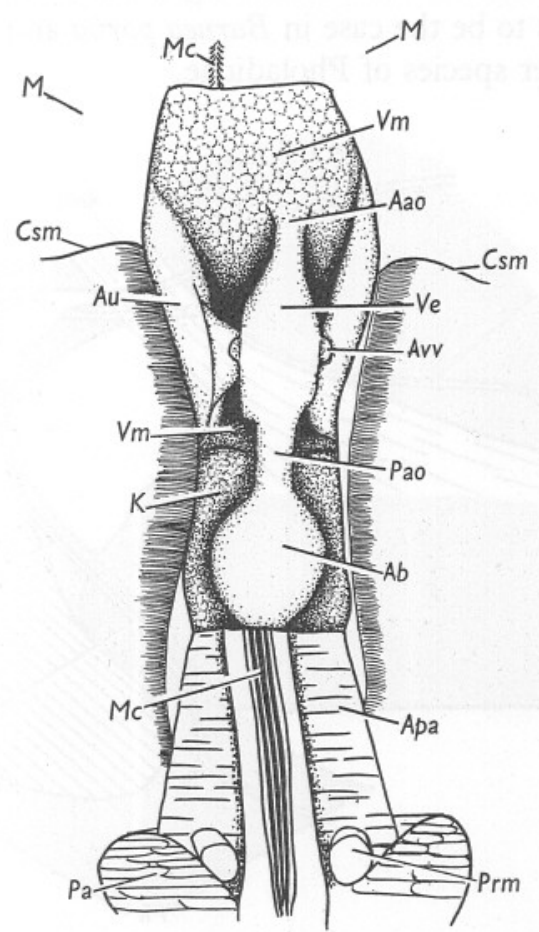

Fig. I4. P. pholadiformis. Dorsal view of the contents of the pericardium. Shell length $I \cdot 9$ in. $\times 4 \cdot 5$. For lettering see pp. $277-8$.

In the Pholadidae, on the other hand, the slightest contraction of the tips of the siphons carries them into the protection of the burrow. Frequent and extensive contractions of the siphons are less likely to occur, and it is not surprising to find that an aortic bulb, if present, is not developed to the same extent as in the case of $P$. pholadiformis. The Pholadidae may be regarded as being more highly adapted to a rock-boring mode of life.

Pelseneer (I906) noted that such highly developed aortic bulbs on the posterior aorta are commonly found in siphonate lamellibranchs. Large aortic bulbs occur in the Veneridae, Petricolidae and Mactridae, for example, 
and also in the Tridacnidae. Although these last are not siphonate, they probably have similar problems in controlling the movement of blood to and from the mantle whenever the shell valves contract or the mantle margins are withdrawn.

The excretory organ of $P$. pholadiformis (Fig. I4, $K$ ) lies anterior to the posterior adductor muscle, being overlaid by the aortic bulb which presses slightly into its dorsal surface. It resembles that of the Pholadidae (Purchon, 1955). There is an anterior oval aperture in the median line, causing the cavities of the distal limbs of the left and right excretory organs to communicate. This was found to be the case in Barnea parva and in Zirphaea crispata, but not in three other species of Pholadidae.

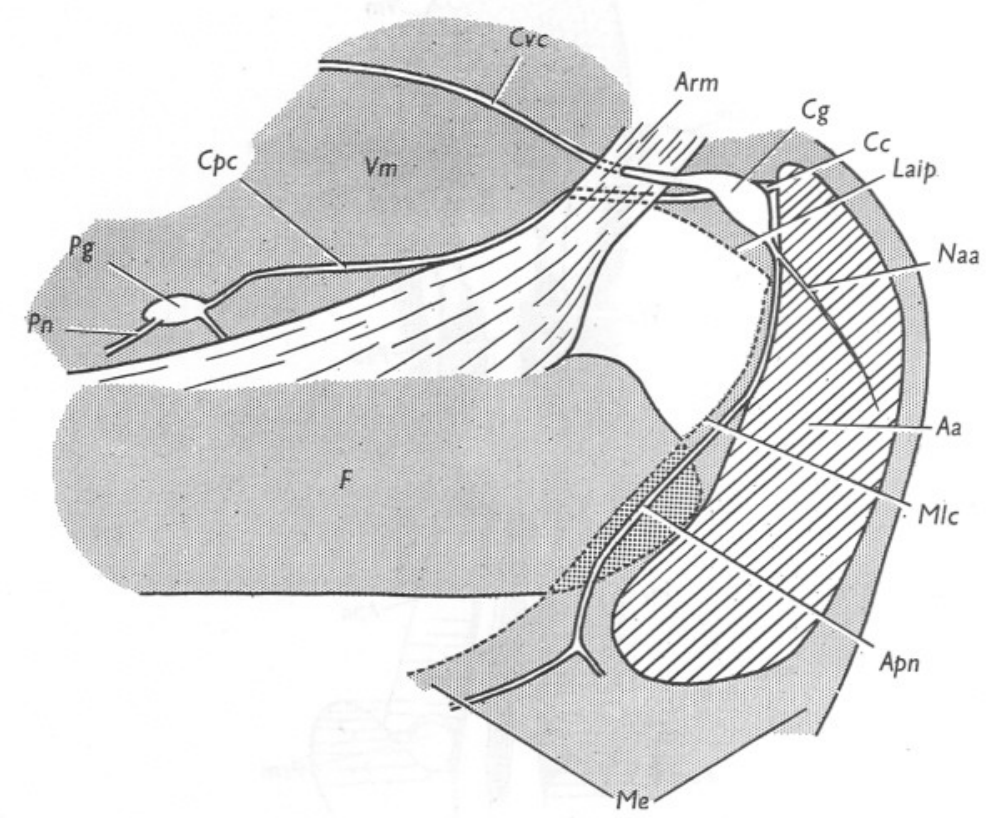

Fig. 15. P. pholadiformis. General dissection of the anterior part of the nervous system. Seen from the right side. Shell length $\mathrm{I} \cdot 8$ in. $\times 9$. For lettering see pp. $277-8$.

\section{The NeRVous System}

The cerebral ganglia are of simple fusiform shape and they lie embedded in a tough fibrous matrix, anterior to the anterior retractor muscle of the visceral mass (Fig. 15, $C g$ ). The cerebral commissure $(C c)$ passes transversely, close to the postero-dorsal margin of the anterior adductor muscle. The cerebropedal connective $(C p c)$ passes backwards internal to the base of the anterior retractor muscle of the visceral mass $(\mathrm{Arm})$ and enters the anterior face of the pedal ganglia. The cerebro-visceral connective penetrates the base of the 
anterior retractor muscle and then passes backwards within the substance of the visceral mass, not close to the epithelium.

The pedal ganglia are large and rounded, and can easily be dissected free from the surrounding tissues. Two large pedal nerves pass out ventrally into the muscles of the foot.

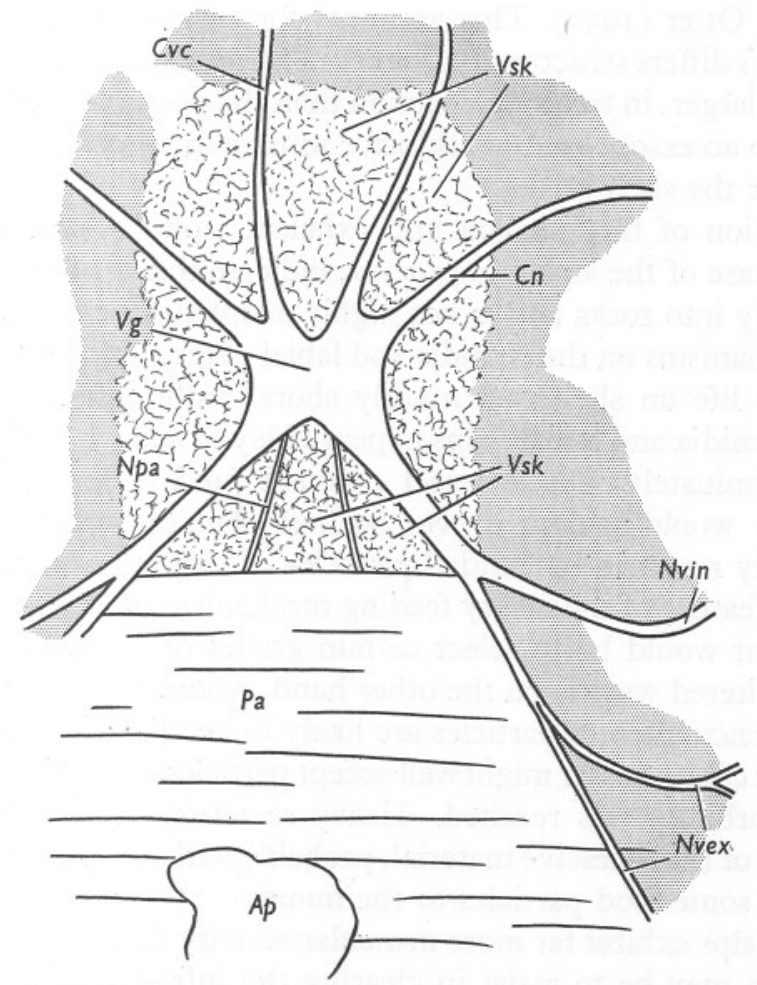

Fig. I6. P. pholadiformis. Ventral view of the posterior part of the nervous system. Shell length $I \cdot 9$ in. $\times 9$. For lettering see pp. $277-8$.

The visceral ganglia lie, not on the ventral surface of the posterior adductor muscle, but a little further forward on the ventral surface of the excretory organ (Fig. I6, Vg). The yellowish ganglia are easily cleared from surrounding tissues. There is no transverse connective between the cerebro-visceral connectives anterior to the visceral ganglia, as is found in the rock-boring Pholadidae (Purchon, I955). The following nerves leave the visceral ganglia: a ctenidial nerve $(\mathrm{Cn})$, a nerve to the posterior adductor muscle $(\mathrm{Npa})$ and a nerve to the siphonal process. The last-named nerve divides into two branches, one serving the inhalant siphon (Nvin) and one the exhalant siphon (Nvex). Each of these subdivides further in the vicinity of the annular valve in the base of the siphon which it serves. There is no macroscopic indication of a siphonal ganglion on the course of the siphonal nerve. 


\section{Discussion}

The presence of a large external ligament and of well-developed hinge teeth in Petricola pholadiformis indicates that the only motion of the shell valves can be by normal opening and closing about the hinge line as an axis, as shown for $P$. lapicida by Otter (1937). This accounts for two other features in which $P$. pholadiformis differs structurally from the Pholadidae: the anterior adductor is smaller, not larger, in transverse section than the posterior adductor muscle, and there is no accessory ventral adductor muscle to secure a ventral point of articulation for the shell valves.

The separation of the inhalant and exhalant siphons, and the ability to introvert the base of the siphonal process, indicate that $P$. pholadiformis does not bore deeply into rocks and is not highly adapted for rock-boring.

Ciliary mechanisms on the ctenidia and labial palps confirm that the species is adapted for life on sheltered, muddy shores rather than on open rocky coasts. The ctenidia and labial palps appear likely to accept particulate matter rather indiscriminately, but to reject mucus-bound material. On an open coast turbidity would seldom if ever be high, but turbulence of the water would probably result in suspended particles of various sizes being present. The essential feature of the ciliary feeding mechanism of an organism in such an environment would be to select certain grades of particles and to reject others. In sheltered waters, on the other hand, where extreme turbidity may be frequently encountered, particles are likely to be of small size. In such an environment, a ciliary feeder might well accept particles almost indiscriminately until excess turbidity was reached. Heavy secretion of mucus would then cause rejection of the excessive material, probably without completely stopping the passage of some food particles to the mouth.

The labial palps exhibit far more muscular activity than those of the Pholadidae, and this may be to assist in clearing the infra-branchial chamber of excessive quantities of mucus-bound material.

The stomach of $P$. pholadiformis, though oriented differently, is of the same fundamental plan as that of the Pholadidae, and it functions in the same manner. The only significant anatomical differences are the anterior displacement of the dorsal hood, and the conjoined style sac and mid-gut in P. pholadiformis. As noted elsewhere for the Pholadidae (Purchon, I955), ciliary sorting mechanisms within the stomach appear to collect particles for passage into the mid-gut; they would seem to hinder passage of food particles into the ducts of the digestive diverticula. This may be brought about by a muscular pumping or suction action, by relative changes in the volumes of the stomach and of the digestive diverticula.

The bulbus on the posterior aorta appeared at first sight to be directly related to the ventricle in its mode of action, but this was later found not to be the case. Frequency of ventricular contraction was found to be directly related to the temperature, whereas that of the bulbus was related, not to the 
water temperature, but to the movements of the siphons. It seems probable that the bulbus acts as a safety valve, protecting the ventricle from sudden return of blood from the contracting siphons. It also probably acts as a reservoir from which blood may flow into the siphons when these are extended again.

P. pholadiformis, as its name implies, has been considered to exhibit some degree of convergent evolution with reference to the Pholadidae, and especially with regard to Barnea candida (L.) which it resembles superficially, and with which it may occur side by side on the same beach.

During the present study over thirty anatomical points were noted in which Petricola pholadiformis differs from all of the British Pholadidae. There can be no doubt that the Pholadidae and the Petricolidae are unrelated. Nevertheless, there are points of resemblance, no less than fourteen of these being noted in which $P$. pholadiformis resembles one or more species of the Pholadidae. But from the point of view of illustrating convergent evolution through adaptation to a rock-boring mode of life only three of these need to be considered, namely:

(a) Fan-shaped groups of guarding cilia arch over and protect the marginal grooves of the ctenidium (compare Pholadidea loscombiana).

(b) Cirrus-like cilia are present along the posterior sides of the ctenidial filaments (compare Barnea parva, B. candida).

(c) The ciliary currents on the ctenidia are of Atkins's type C (I c) (Atkins, I937b) (compare Barnea candida). An opinion has been expressed elsewhere (Purchon, 1955) that this ciliary pattern on the ctenidia of B. candida and Petricola pholadiformis has been achieved by simplification of the ciliary mechanisms on three of the ctenidial lamellae and not by complication of the ciliary mechanisms on the fourth lamella.

It seems probable that there must have been some measure of adaptive radiation in the Pholadidae, and also, doubtless, a certain amount of evolutionary 'drift' in each species. Due to variation in structure from species to species within the Pholadidae, it seems inevitable that there should be fortuitous similarities in structure between $P$. pholadiformis and individual members of the Pholadidae. Though the superficial resemblance is to Barnea candida, similarities also exist between Petricola pholadiformis and other members of the Pholadidae, but these similarities appear to be fortuitous.

\section{SUMMARY}

Living specimens of Petricola pholadiformis Lamarck were obtained from Burnham-on-Crouch, Essex.

Studies of the principal organ systems were made on the living animal, particular attention being paid to the ciliary feeding and cleansing mechanisms in the mantle cavity, and the ciliary sorting mechanisms within the stomach. The action of the bulbus on the posterior aorta was also studied. 
A detailed comparison was made between $P$. pholadiformis and all the British species of Pholadidae. Thirty anatomical features were found in which $P$. pholadiformis differed from all of the Pholadidae, and fourteen features in which $P$. pholadiformis resembled one or more species of Pholadidae. It was concluded that these resemblances were purely fortuitous.

\section{REFERENCES}

AtKINs, D., I937a. On the ciliary mechanisms and inter-relationships of lamellibranchs. Part II. Sorting devices on the gills. Quart. F. micr. Sci., Vol. 79, pp. 339-73.

I $1937 b$. On the ciliary mechanisms and inter-relationships of lamellibranchs. Part III. Types of lamellibranch gills and their food currents. Quart. F. micr. Sci., Vol. 79, pp. 375-421.

Calman, W. T., I919. Marine boring animals injurious to submerged structures. Brit. Mus. (Nat. Hist.) Economic Series No. ro, 34 pp.

Calman, W. T. \& Crawford, G. I., 1936. Marine boring animals injurious to submerged structures. Brit. Mus. (Nat. Hist.) Economic Series No. Io, 38 pp.

CoE, W. R., I943. Development of the primary gonads and differentiation of sexuality in Teredo navalis and other pelecypod molluscs. Biol. Bull., Woods Hole, Vol. 84, pp. $178-86$.

HaAs, F., I929-40. Bivalvia. Bronns Klassen und Ordnungen des Tierreichs, Bd.3, Abt. 3. Leipzig.

Lamy, E., I923. Révision des Venerupis et des Petricola vivants. F. Conchyliol., T. 67, pp. $275-359$.

MorSE, E. S., I9I9. Observations on living lamellibranchs of New England. Proc. Boston Soc. nat. Hist. Vol. 35, pp. 139-96.

Otter, G. W., I937. Rock-destroying organisms in relation to coral reefs. Sci. Rep. Gr. Barrier Reef Exped. 1928-9, Vol. I, pp. 323-52.

Pelseneer, P., 1906. Mollusca. A Treatise on Zoology, ed. E. Ray Lankester, Pt. 5. London.

_- I9I. Les Lamellibranches de l'expédition du Siboga. Partie Anatomique. Siboga Expeditie, Monographie 53a, Leiden.

Purchon, R. D., 1955. The structure and function of the British Pholadidae (Rockboring Lamellibranchia). Proc. Zool. Soc. Lond. (in the Press).

RIDEwood, W. G., I903. On the structure of the gills of the Lamellibranchia. Phil. Trans. B, Vol. I94, pp. I47-284.

SchlesCh, H., I932. Petricola pholadiformis Lamk. in Europe. Naturalist, Lond., No. 906, pp. 213-I4.

Sikes, F. H., I910. Crepidula fornicata and Petricola pholadiformis in the Medway. f. Conch., Vol. 13, p. 108.

WHITE, K. M., I942. The pericardial cavity and the pericardial gland of the Lamellibranchia. Proc. malac. Soc. Lond., Vol. 25, pp. 37-88.

WINCKWorth, R., I932. The British Marine Mollusca. F. Conch., Vol. I9, pp. 2 I I-52.

YoNGE, C. M., I926. The disappearance of the crystalline style. Nature, Lond., Vol. II 7 , p. 691 .

- 1948. Formation of siphons in Lamellibranchia. Nature, Lond., Vol. I6I, p. I98.

- 1949. On the structure and adaptations of the Tellinacea, deposit-feeding Lamellibranchia. Phil. Trans. B, Vol. 234, pp. 29-76. 


\section{ABBREVIATIONS USED IN THE FigURES}

Aa Anterior adductor (muscle, or scar)

Aao Anterior aorta

$\mathrm{Ab} \quad$ Aortic bulb

Alm Anterior lip of the mouth

Alod Ascending lamella of the outer demibranch

Ant Anterior

Ap Anal papilla

Apa Accessory posterior adductor muscle

$A p n$ Anterior pallial nerve

Arm Anterior retractor muscle of the visceral mass

$A u \quad$ Auricle

Avv Auriculo-ventricular valve

$B p \quad$ Brown pigment on the wall of the style sac

$\mathrm{Ca}$ Ctenidial axis

Cc Cerebral commissure

$\mathrm{Cg}$ Cerebral ganglion

$\mathrm{Cn}$ Ctenidial nerve

$C p c \quad$ Cerebro-pedal connective

Csm Cut surface of the mantle

Cssi Combined style sac and mid-gut

Cvc Cerebro-visceral connective

Dd Openings into the digestive diverticula of the right side

Ddd Ducts of the digestive diverticula

$D d l$ The left caecum, into which open the majority of the ducts of the digestive diverticula on the left side of the body

$D d r \quad$ The right caecum, into which open all of the ducts of the digestive diverticula on the right side of the body

Dh Dorsal hood

$D h^{\prime} \quad$ Distal end of the dorsal hood

$\mathrm{Dl}$ Dividing line between the musculature of the foot and the glandular visceral mass

Dlid Descending lamella of the inner demibranch

Dwlp Dorsal wall of the left pouch

Ex Exhalant aperture

F Foot

Fml Anterior limit to the fusion of the mantle lobes

Gi Intestinal groove

Gs Gastric shield

$H t \quad$ Hinge teeth

Ia Areas of ciliary inactivity

Id Inner demibranch

In Inhalant aperture

$K \quad$ Excretory organ
$L \quad$ Ligament

$L^{\prime} \quad$ Split in the ligament

Laid Line of attachment of the inner demibranch

Laip Line of attachment of the right inner labial palp

Ls The left pouch of the stomach

$M \quad$ Mantle

Mc Median mantle crest

$\mathrm{Me} \quad$ Thickened mantle edge

$\mathrm{Mg} \quad$ Mid-gut

Mlc Line along which the right mantle lobe has been cut away

Mo Mouth

Naa Nerve to the anterior adductor muscle

$\mathrm{Npa}$ Nerve to the posterior adductor muscle

Nvin Nerve to the muscles and valve of the inhalant siphon

Nvex Nerve to the muscles and valve of the exhalant siphon

Oc Oralward current

Od Outer demibranch

Odh Opening of the dorsal hood into the stomach

Oe Oesophagus

Oes Opening of the oesophagus into the stomach

Omg Origin of the mid-gut at the base of the style sac

$O m g^{\prime}$ Origin of the mid-gut from the stomach

Olm Outer and middle lobes of the mantle edge

Os $\quad$ Outer surface of shell

Oss Opening of the style sac into the stomach

$P \quad$ Periostracum

$\mathrm{Pa}$ Posterior adductor (muscle, or scar)

Pao Posterior aorta

$P c \quad$ Pericardium

Pf Posterior end of the foot

$\mathrm{Pg} \quad$ Pedal ganglia

$\mathrm{Pl} \quad$ Pallial line

Plm Posterior lip of the mouth

Pm Pedal retractor muscle

$P n \quad$ Pedal nerves

Post Posterior

Prm Posterior retractor muscle of the visceral mass (muscle, or scar)

Ps Pallial sinus

$R \quad$ Rectum

$\mathrm{Ra}$ Region where small particles accumulate 
Rilp Right inner labial palp

$\mathrm{Rml}$ Portion of right mantle lobe, turned downwards

$R d h$ Roof of the dorsal hood of the stomach, turned outwards

Rolp Right outer labial palp

Rpc Roof of the pericardium

$S \quad$ Septum in the siphonal process

$\mathrm{Sa} \quad$ Sorting area which extends from the interior of the dorsal hood to the intestinal groove

$\mathrm{Sa}^{\prime}$ Additional sorting area within the dorsal hood, which passes out towards the oesophagus

$S a^{\prime \prime} \quad$ Extension of $S a^{\prime}$ which lies ventral to the opening of the oesophagus into the stomach

$S a^{\prime \prime \prime}$ Sorting area within the left pouch of the stomach

Sc Supra-branchial chamber
Srm Line of attachment of the siphonal retractor muscles to the shell

St Stomach

Tf Tip of the foot, greatly contracted

Ty Major intestinal typhlosole

$T y^{\prime} \quad$ The part of the major intestinal typhlosole which passes transversely across the stomach from the aperture of the left caecum to that of the right caecum

U Umbo

$V \quad$ Valves in the base of the exhalant and inhalant siphons

Ve Ventricle

$\mathrm{Vg}$ Visceral ganglia

$V m$ Visceral mass

Vsf Velum surrounding the foot

Vsk Ventral surface of the excretory organ

$W p \quad$ Weak plication of the ctenidia 